\title{
Legal Dictionary Menggunakan Aplikasi Android
}

\author{
Nia Ekawati ${ }^{1}$, Rizki Tri Anugrah Bhakti ${ }^{2}$ \\ ${ }^{1}$ Jurusan Teknik Informatika, Fakultas Teknik dan Komputer, Universitas Putera Batam \\ ${ }^{2}$ Jurusan Ilmu Hukum, Fakultas Ilmu Sosial dan Humaniora, Universitas Putera Batam \\ 1niaekawati1@gmail.com, ${ }^{2}$ rizki.tri.ab@gmail.com
}

\begin{abstract}
The purpose of this study is to help the people of Batam City who want to know the legal terms contained in the form of a legal dictionary with the help of an android application. Every person who studies the legal dictionary must carry the dictionary everywhere. But if it is made in the form of an application, the legal dictionary does not need to be taken anywhere. Simply by opening the android application looking for the desired term, it makes it easy for anyone who wants to know about legal terms. The results obtained are an android application as a digital dictionary as a legal dictionary especially for the people of Batam City, and generally for the State of Indonesia.
\end{abstract}

Keywords: Android, Applications, Dictionary, Legal

\section{Abstrak}

Tujuan penelitian ini adalah membantu masyarakat Kota Batam yang ingin mengetahui istilah-istilah hukum yang tertuang dalam bentuk kamus hukum dengan bantuan aplikasi android. Istilah tersebut dapat dinamakan kamus hukum. Setiap orang yang mempelajari kamus hukum tentu harus membawa kamus tersebut kemana-mana. Namun jika dibuat dalam bentuk sebuah aplikasi, kamus hukum tersebut tidak perlu lagi dibawa kemana-mana. Cukup dengan membuka aplikasi android mencari istilah yang diinginkan, maka memudahkan bagi siapa saja yang ingin tahu mengenai istilah-istilah hukum. Hasil luaran yang didapat adalah sebuah aplikasi android sebagai kamus digital dengan sebutan legal dictionary khususnya untuk masyarakat Kota Batam, dan umumnya untuk Negara Indonesia.

Kata kunci: Android, Aplikasi, Kamus, Hukum

\section{PENDAHULUAN}

Smartphone saat ini memiliki jumlah pengguna yang cukup banyak. Menurut [1] Berdasar data penjualan global smartphone untuk end-user dari kuartal 12009 s.d kuartal tahun 2016, diperoleh data pada info grafis di bawah ini:

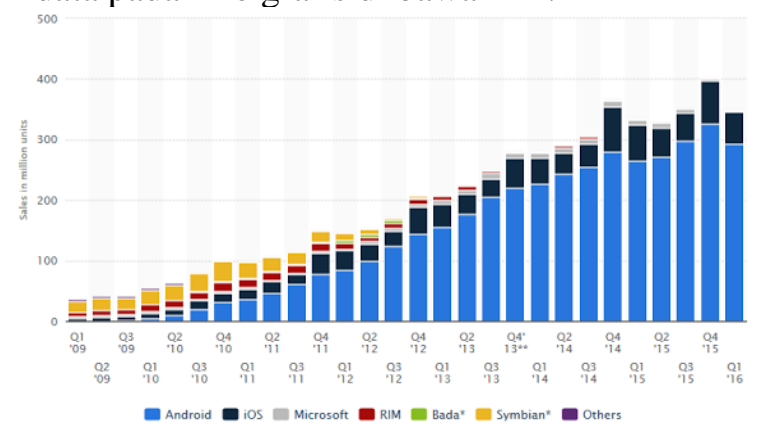

Gambar 1. Total Jumlah Pengguna Smartphone Seluruh Dunia 
Statistik ini menunjukkan penjualan smartphone global untuk pengguna akhir (enduser) berdasar sistem operasi yang digunakan, data dari kuartal pertama 2009 dengan data keuangan triwulan terbaru. Pada kuartal pertama 2010, Apple menjual 8,36 juta smartphone dengan iOS mereka. Pada tahun 2010, 296.650.000 smartphone terjual di seluruh dunia. Melihat data total jumlah pengguna smartphone seluruh dunia, terlihat sistem operasi android saat ini yang banyak digunakan oleh pengguna.

Menurut penelitian [2] mengungkapkan bahwa: Bahasa Jepang dapat dibilang sebagai salah satu bahasa yang patut dipelajari dan diminati. Selain kebudayaan Jepang seperti musik dan pakaian, Jepang kini semakin dikenal dan diminati oleh masyarakat Indonesia. Perkembangan smartphone yang mengusung sistem operasi android beberapa tahun kebelakang banyak dipakai karena memiliki beragam fitur yang dapat memenuhi kebutuhan dan daya tarik tersendiri bagi user. Keberhasilan penggunaan sebuah aplikasi dilihat dari interaksi user dengan user interfacenya. User harus merasa puas dengan semua informasi yang disediakan dan merasa nyaman saat berinteraksi dengan sistem. Tujuan dari penelitian ini adalah menghasilkan rancangan aplikasi kamus dasar bahasa Jepang berbasis android menggunakan metode User Centered Design (UCD) untuk menangkap kebutuhan user. Pengumpulan data menggunakan studi literatur, wawancara, dan kuesioner. Pendekatan UCD membantu perancangan sistem interaktif yang lebih berpusat pada pengguna dan sasaran UCD lebih dari sekedar membuat produk yang berguna bagi usernya. Penelitian ini menghasilkan rancangan aplikasi kamus dasar bahasa Jepang berbasis android menggunakan metode User Centered Design yang sesuai dengan kebutuhan user.

Berdasarkan data yang telah disampaikan diatas, tentu para programmer berusaha membuat aplikasi-aplikasi yang dapat dioperasikan pada sistem android. Salah satunya adalah Legal DictionaryBerbasis Android. Saat ini, pendidikan di Indonesia memiliki berbagai jenis bidang ilmu yang dapat dipelajari seperti ilmu hukum, hukum di Indonesia saat ini dinyatakan secara tertulis dalam pasal 1 ayat 3 UUD 1945 berdasarkan hasil amandemen. Berdasarkan penelitian [3] Penegakan hukum ditujukan guna meningkatkan ketertiban dan kepastian hukum dalam masyarakat. Hal ini dilakukan antara lain dengan menertibkan fungsi, tugas dan wewenang lembaga-lembaga yang bertugas menegakkan hukum menurut proporsi ruang lingkup masing-masing, serta didasarkan atas sistem kerjasama yang baik dan mendukung tujuan yang hendak dicapai. Tingkat perkembangan masyarakat tempat hukum diberlakukan mempengaruhi pola penegakan hukum, karena dalam masyarakat modern yang bersifat rasional dan memiliki tingkat spesialisasi dan diferensiasi yang tinggi pengorganisasian penegak hukumnya juga semakin kompleks dan sangat birokratis.

Ilmu hukum dibagi menjadi dua bagian yakni hukum pidana dan hukum perdata. Hukum pidana berkaitan dengan pembunuhan, pemerkosaan, terorisme, dan kriminalitas lainnya. Sedangkan hukum perdata berkaitan dengan perjanjian, waris, dan perkawinan. Berdasarkan dua pembagian tersebut tentu ada istilah-istilah hukum yang akan dipakai dan berbeda maksud serta tujuannya. Istilah-istilah hukum tersebut dapat dinamakan kamus hukum. Setiap orang yang mempelajari Legal Dictionarytentu harus membawa kamus tersebut kemana-mana. Namun apabila dapat dibuat sebuah aplikasi android, Legal Dictionary tersebut tidak perlu lagi dibawa kemana-mana. Cukup dengan membuka aplikasi android mencari istilah yang diinginkan, maka memudahkan bagi siapa saja yang ingin tahu mengenai istilah-istilah hukum. Khususnya masyarakat Kota Batam dapat menggunakan aplikasi ini sebagai pengetahuan atau kebutuhan dari penggunanya.

Berdasarkan penelitian [4] diperoleh fakta: Tujuan yang ingin dicapai dari aplikasi ini adalah mengoptimalkan Aplikasi Mobile Zagiyan (Zaringan Digital Nelayan) Dalam Menunjang Produktivitas Dan Keselamatan, Dan Kesehatan Nelayan (Studi Kasus 
Kelompok Nelayan Percut). Target utama adalah mengimplementasikan software dan system aplikasi mobile Zagiyan dengan berbagai fitur seperti fitur harga ikan, laporan pendapatan, info koperasi, info puskesmas, check in, report, panic dan lain lain. Hasil dari kegiatan ini adalah Nelayan mengenal aplikasi android Zagiyan untuk peningkatan produktivitas, keselamatan dan kesehatan masyarakat pesisir. Tingkat Keakuratan aplikasi ini mencapai 90\%. Aplikasi ini juga telah diterapkan di beberapa daerah yaitu Bagan Deli dan Percut .Aplikasi ini diharapkan menjadi solusi bagi seluruh nelayan Indonesia.

Tujuan penelitian ini adalah membantu masyarakat Kota Batam yang ingin mengetahui istilah-istilah hukum yang tertuang dalam bentuk kamus hukum dengan bantuan aplikasi android.

\section{METODE PENELITIAN}

\subsection{Pengumpulan Data}

Langkah awal yang akan dilakukan, baru merambah pada satu bidang ilmu saja, yaitu ilmu hukum. Karena seperti yang diketahui Indonesia adalah Negara Hukum, diharapkan dengan bantuan legal dictionary dapat membantu masyarakat umum yang tidak memahami istilah-istilah hukum. Tahapan yang muncul adalah sebagai berikut. (a) melakukan analisis program untuk kamus hukum; (b) melakukan proses desain program pada kamus hukum; dan (c) melakukan proses test program pada kamus hukum.

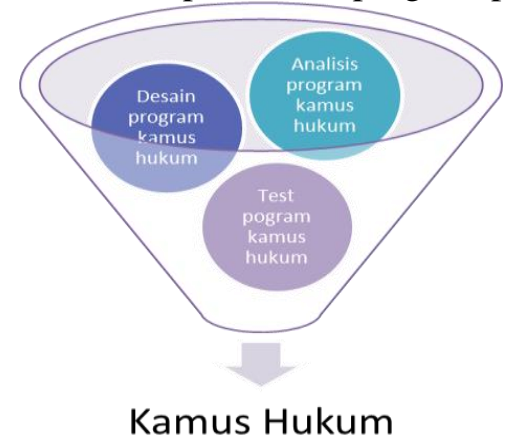

\section{Gambar 2. Tahapan pembuatan kamus hukum}

\subsection{Konsep Teori}

\subsubsection{Sistem Pakar}

Menurut [5] Sistem pakar adalah aplikasi berbasis komputer yang digunakan untuk menyelesaikan masalah sebagaimana yang dipikirkan oleh pakar. Pakar yang dimaksud di sini adalah orang yang mempunyai keahlian khusus yang dapat menyelesaikan masalah yang tidak dapat diselesaikan oleh orang awam. Sebagai contoh, dokter adalah seorang pakar yang mampu mendiagnosis penyakit yang diderita pasien, serta dapat memberikan penatalaksanaan terhadap penyakit tersebut. Tidak semua orang dapat mengambil keputusan mengenai diagnosis dan memberikan penatalaksanaan suatu penyakit. Contoh yang lain, montir adalah seorang yang punya keahlian dan pengalaman dalam menyelesaikan kerusakan mesin motor/mobil, psikolog adalah orang yang ahli dalam memahami kepribadian seseorang, dan lain-lain.

\subsubsection{Android Studio}

Menurut [6] Android adalah sistem operasi berbasis linux yang dirancang untuk perangkat bergerak layar sentuh seperti telepon pintar dan computer tablet. Android 
awalnya dikembangkan oleh Android, Inc., dengan dukungan finansial dari google, yang kemudian membelinya pada tahun 2005. Sistem operasi ini dirilis secara resmi pada tahun 2007, bersamaan dengan didirikannya Open handset Alliance, konsorsium dari perusahaan-perusahaan perangkat keras, perangkat lunak, dan telekomunikasi yang bertujuan untuk memajukan standar terbuka perangkat seluler.Ponsel Android pertama mulai dijual pada bulan Oktober 2008.

\subsubsection{Ilmu Hukum}

Menurut [7] Mengapa sulit merumuskan hukum? "Hampir semua sarjana hukum memberikan batasan hukum yang berlainan", kata Prof. van Apeldoorn. Sebagai gambaran, Prof. Sudirman Kartohadiprodjo, S.H., lalu memberikan contoh- contoh tentang definisi hukum yang berbeda-beda, sebagai berikut: (a) Aristoteles: Particular law is that which each community lays down and applies to its own members. Universal law is the law of nature. (b) Leon Duguit: Hukum ialah aturan tingkah laku para anggota masyarakat, aturan yang daya penggunaannya pada saat tertentu diindahkan oleh suatu masyarakat sebagai jaminan dari kepentingan bersama dan yang jika dilanggar menimbulkan reaksi bersama terhadap orang yang melakukan pelanggaran itu. (c) Immanuel Kant: Hukum ialah keseluruhan syarat-syarat yang dengan ini kehendak bebas dari orang yang satu dapat menyesuaikan diri dengan kehendak bebas dari orang yang lain, menurut peraturan hukum tentang kemerdekaan.

\subsubsection{Hukum Pidana}

Menurut [8] Hukum pidana adalah bagian dari keseluruhan hukum yang berlaku di suatu Negara, yang mengadakan dasar-dasar dan aturan-aturan untuk: (a) Menentukan perbuatan-perbuatan mana yang tidak boleh dilakukan, yang dilarang, dengan disertai ancaman atau sanksi yang berupa pidana tertentu bagi barang siapa melanggara larangan tersebut. (b) Menentukan kanap dan dalam hal-hal apa kepada mereka yang telah melanggar larangan-larangan itu dapat dikenakan atau dijatuhi pidana sebagaimana yang telah diancamkan. (c) Menentukan dengan cara bagaimana pengenaan pidana itu dapat dilaksanakan apabila ada orang yang disangka telah melanggar larangan tersebut.

\subsubsection{Hukum Perdata}

Menurut [9] Hukum Perdata adalah segala aturan hukum yang mengatur hubungan hukum antara orang yang satu dengan orang yang lain dalam hidup bermasyarakat. Hubungan hukum perdata tersebut dapat terjadi karena: (a) Perjanjian antara pihak yang satu dan pihak yang lain, misalnya jual beli, sewa menyewa, utang-piutang, tukarmenukar, dan pemberian kuasa. (b) Ketentuan undang-undang, yang bermanfaat atau saling menguntungkan bagi pihak-pihak, misalnya, perwakilan sukarela, pembayaran tanpa utang, perbuatan menurut hukum, dan perwarisan. (c) Ketentuan undang-undang, yang merugikan orang lain, misalnya perbuatan melawan hukum.

\subsection{Perancangan Sistem}

Rancangan penelitian mewakili proses yang dikerjakan pada aplikasi legal dictionary Menggunakan Aplikasi Android meliputi flowchat dan desain program sebagai berikut: 


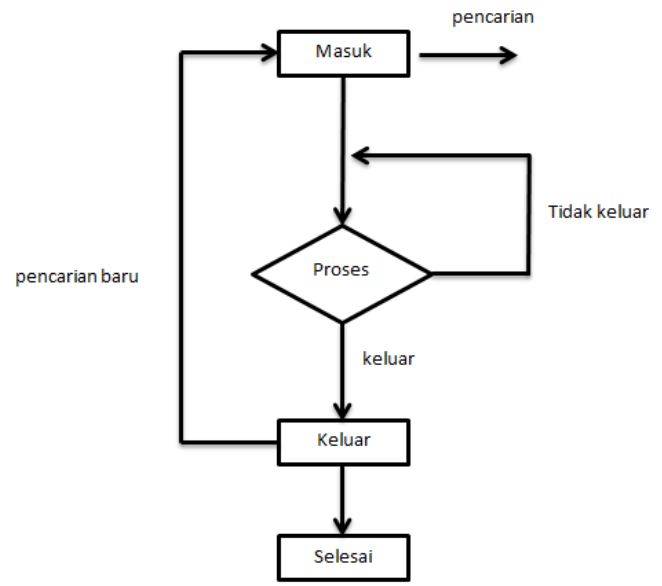

\section{Gambar 3. Flowchart Aplikasi Legal Dictionary Menggunakan Aplikasi Android}

Pada gambar 3, menjelaskan mengenai cara kerja program dalam proses pencarian data didalam program legal dictionary. Berikut desain program yang akan dibuat :

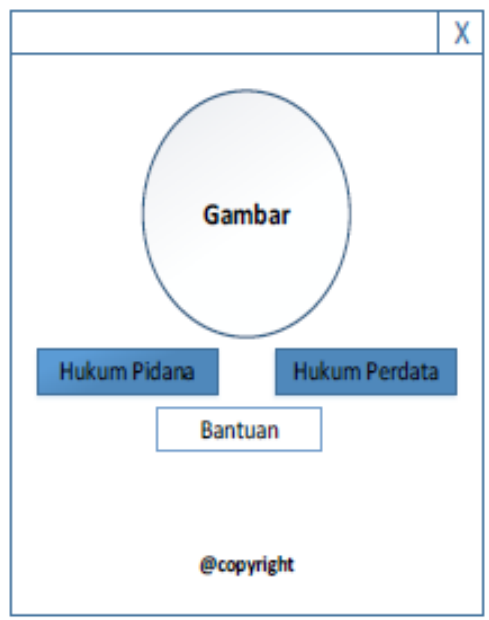

\section{Gambar 4. Tampilan Awal Program}

Pada gambar 4, desain tampilan awal program pada saat pengguna akan menggunakan program aplikasi legal dictionary. 


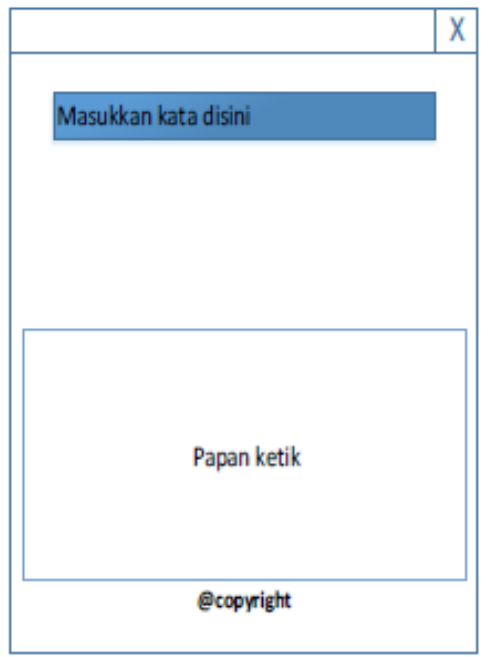

\section{Gambar 5. Tampilan Program Proses Pencarian Kata}

Pada gambar 5, desain tampilan program proses pencarian kata pada saat pengguna akan mencari istilah-istilah hukum pada program aplikasi legal dictionary.

\section{HASIL DAN PEMBAHASAN}

Hasil penelitian yang dilakukan beberapa proses, diantaranya sebagai berikut:

1. Instal aplikasi pada smartphone android

Bagian ini berisi data file berekstensi .apk yang akan diinstalkan pada smartphone android. Adapun tampilannya adalah sebagi berikut:

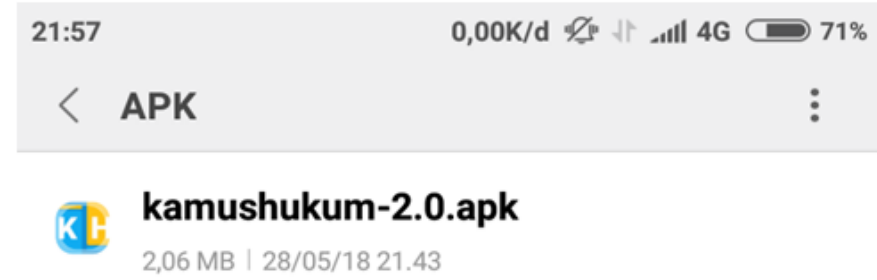

\section{Gambar 6. File Instalasi Aplikasi Kamus Hukum}

2. Tampilan awal setelah aplikasi diinstal pada smartphone android

Pengguna diberikan pilihan untuk melewati tampilan awal untuk masuk pada proses pencarian, atau lanjut untuk masuk dalam pengenalan tentang aplikasi kamus hukum. Adapun tampilannya adalah sebagi berikut: 


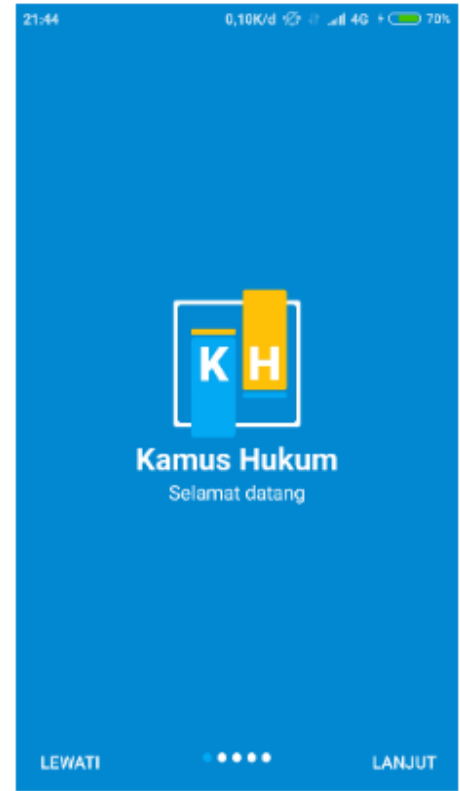

\section{Gambar 7. Tampilkan Awal Setelah Instalasi Aplikasi}

3. Tampilan utama aplikasi kamus hukum/legal dictionary

Pengguna diberikan dua pilihan dalam pencarian pada kamus hukum, yakni Hukum Pidana dan Hukum Perdata. Adapun tampilannya adalah sebagi berikut:

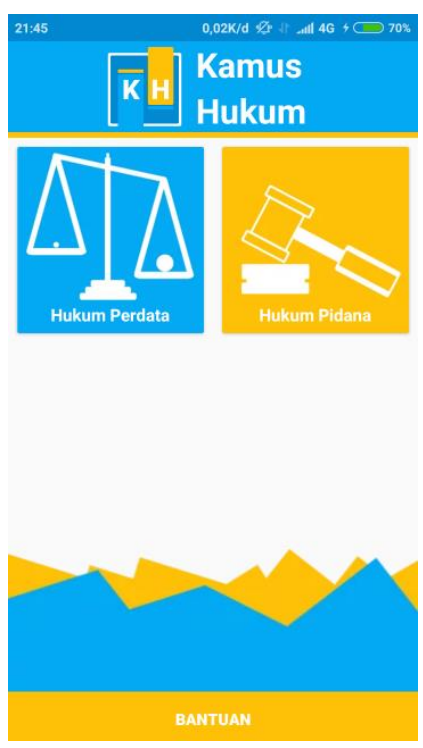

\section{Gambar 8. Tampilan Utama Aplikasi Kamus Hukum}

4. Tampilan pencarian hukum perdata

Bagian ini merupakan proses sebagai pengguna dalam langkah awal untuk mencari istilah-istilah hukum, salah satu pengguna dapat mengambil istilah tersebut dalam pencarian hukum perdata. Adapun tampilannya adalah sebagi berikut ; 


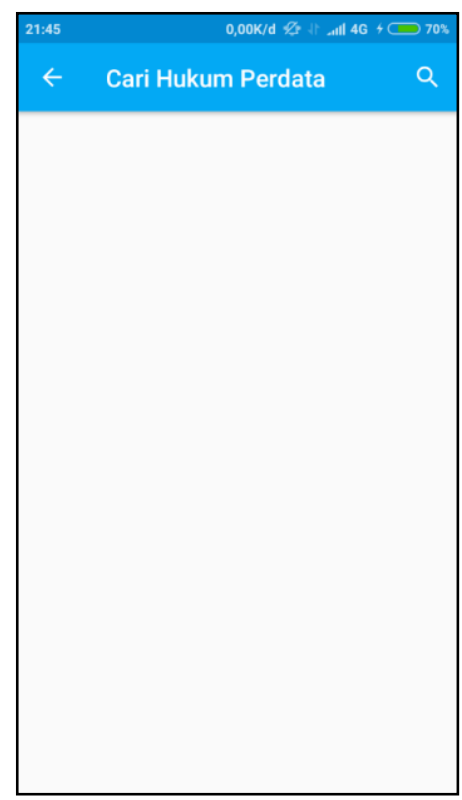

\section{Gambar 9. Tampilan Pencarian Hukum Perdata}

5. Tampilan hasil pencarian istilah pada hukum perdata

Bagian ini menampilkan hasil pencarian, yang telah diproses sebelumnya pada gambar 10, salah satu istilah dalam kamus hukum adalah Abnormal. Adapun tampilannya adalah sebagi berikut :

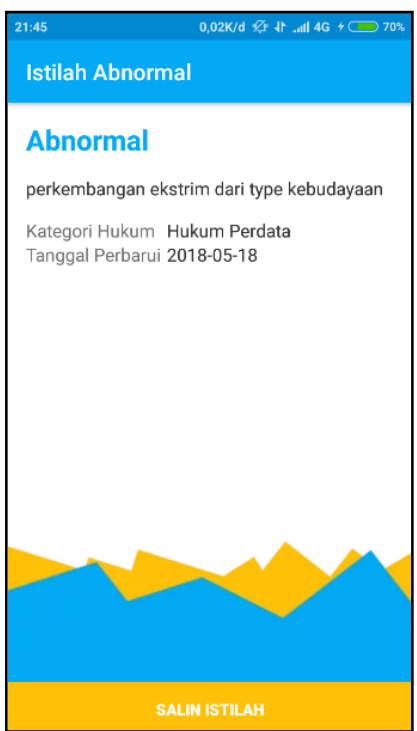

\section{Gambar 10. Tampilan Hasil Pencarian Istilah Pada Hukum Perdata}

\section{KESIMPULAN}

Kesimpulan pada penelitian ini adalah aplikasi android legal dictionary membantu pengguna yang ingin mengetahui istilah-istilah hukum, baik pada kalangan mahasiswa, praktisi, dan tenaga pendidik dibidang hukum atau sebagai pengetahuan diluar lingkungan hukum. 


\section{SARAN}

Saran pada penelitian legal dictionary menggunakan aplikasi android adalah aplikasi yang dibuat saat ini masih sebatas aplikasi mesin pencarian istilah dengan cara diketik terlebih dahulu, namun kedepan aplikasi ini dapat dikembangkan dengan bantuan menggunakan voice atau suara untuk memanggil istilah-istilah hukum tersebut.

\section{DAFTAR PUSTAKA}

[1] Et.co.id, "Total Jumlah Pengguna Smartphone Seluruh Dunia,” 2016, p. 1.

[2] S. Perdanawati, Linda; Setiajid, "Aplikasi Kamus Dasar Bahasa Jepang Berbasis Android Menggunakan Metode User Centered Design," Telematika, vol. 10, no. 2, pp. 77-91, 2017.

[3] Sanyoto, "Penegakan Hukum Di Indonesia," J. Din. Huk., vol. 8, no. 3, pp. 1-6, 2008.

[4] H. Harumy, T Henny; Amrul, "Aplikasi Mobile Zagiyan ( Zaringan Digital Nelayan) Dalam Menunjang Produktivitas Dan Keselamatan, Dan Kesehatan Nelayan ( Studi Kasus Kelompok Nelayan Percut)," IT J. Res. Dev., vol. 2, no. 2, pp. 52-61, 2018.

[5] Kusrini, Aplikasi Sistem Pakar. Yogyakarta: Andi Offset, 2008.

[6] Wikipedia.org, "Andorid (Sistem Operasi)," 2017, p. 1.

[7] K. K. Christine, Pengantar Ilmu Hukum Indonesia. Jakarta: Rineka Cipta, 2011.

[8] Moeljatno, Asas-Asas Hukum Pidana. Jakarta: Rineka Cipta, 2008.

[9] A. Muhammad, Hukum Perdata Indonesia. PT Citra Aditya Bakti, 2010. 